\title{
Morphological Formation of the Regenerated Cellulose Membranes Recovered from Its Cuprammonium Solution Using Various Coagulants
}

\author{
Miki Inamoto, Ikuya MiYamoto, Tomoko Hongo, \\ Michitaka Iwata, and Kunihiko OKaJIMA \\ Fundamental Research Laboratory of Natural \& Synthetic Polymers, \\ Asahi Chemical Industry Co., Ltd. \\ 11-7 Hacchonawate, Takatsuki, Osaka 569, Japan
}

(Received October 20, 1995)

\begin{abstract}
Morphological formation of the regenerated cellulose membranes from its cuprammonium hydroxide solution was investigated in connection with the change in the complex form between cellulose and cuprammonium hydroxide and material transportation during coagulation process using various aqueous coagulants $\left(\mathrm{H}^{+}, \mathrm{Na}^{+}, \mathrm{K}^{+}, \mathrm{NH}_{4}^{+}, \mathrm{Ca}^{2+}\right.$, $\mathrm{Mg}^{2+}$ with various counter ions). Scanning electron microscopically observation revealed that the morphological distribution estimated by pore size distribution in the thickness direction of the membranes are categorized into four types (two gradient types, homogeneously dense type and skin/void type) depending on $\mathrm{pH}$ and cation species (not anion species) of the coagulants, which are in turn the determinant of water permeability of the membrane. The each type of morphology was proved well correlated to the change in circular dichroism (CD) spectra taken for the coagulated gels as a function of coagulation time, which was also correlated to the transportation of ammonia and cupric ion from the original cellulose solution into the coagulants. Thus, the controlling of the morphology of the membranes from cellulose/cuprammonium hydroxide solution could be possible by simply selecting the cationic species of coagulants in general and the membrane with gradient pore distribution and having a relatively higher water permeability is obtainable by acid or ammonium salts as coagulant.

KEY WORDS Regenerated Cellulose Membrane / Morphological Distribution / Cuprammonium Cellulose / Coagulants / Circular Dichroism / Transportation /
\end{abstract}

The regenerated cellulose membrane has occupied an important position as a dialyzer for hemo-dialysis and has been utilized world-widely. However, a long term usage of this membrane has been reported to sometimes cause chronicle side-reaction such as amyloidosis to patients with renal insufficiency by accumulation of $\beta_{2}$-micro globulin $\left(\beta_{2}\right.$-MG) having low molecular weight ranging $10^{4}-5.5 \times 10^{4}$ in body tissue. ${ }^{1}$ Therefore, attempts have been made to design the membrane morphology (or pore size distribution) so as to dialyze out $\beta_{2}$-MG but keeping proteins which are biologically important, by means of molecular sieving principle. This inevitably leads to an intention for the development of the membrane with gradient pore size distribution in cross sectional direction, either one of which has relatively large pore size and other has relatively small pore size, hence, guaranteeing the large water permeability and good retention of necessary proteins.

So far, some coagulation/regeneration systems have been industrially used in the case where the cellulose dissolved in cuprammonium hydroxide solution is the original dope for shaping. The water coagulation/acid regeneration system has been commonly employed for regenerated fiber formation and the aqueous (aq) alkaline coagulation/acid regeneration and organic solvent-water mixture coagulation/acid regeneration systems are for membrane formation. For the former case, it has been very recently found that the regenerated fiber has a cross-section with at least three phases each having different molecular packings (or morphology) and molecular orientation. ${ }^{2}$ For the latter case, the membrane obtained by alkaline coagulation, which is ordinary used for hemo-dialysis, is said to have rather even and densely coagulated morphology (average pore $\operatorname{size}=$ few $\mathrm{nm}$ ) in the cross sectional direction, leading to relatively low water permeability. ${ }^{3}$ The membrane having relatively large pore size $(>15 \mathrm{~nm})$ with some gradient structure in pore size distribution, has been obtained by organic solvent-water mixture coagulation system, ${ }^{4}$ and utilized for separation of blood components. ${ }^{5}$ The latter membrane was developed principally based on phase separation study made by Kamide et al. ${ }^{6}$ Note that the productivity of the membrane, if compared between the above two methods, is much higher for the former system. Recently, authors have confirmed that cellulose exists as $\delta$ chelate structure with coordination of cuprammonium ions to hydroxyl groups at $C_{2}$ and $C_{3}$ positions of glucopyranose unit in cuprammonium hydroxide solution. ${ }^{7}$ In addition, authors also revealed that the similar cellulose/cuprammonium hydroxide complex as that in solution could exist even in a solid state. ${ }^{8}$ This means that the change in the chelate or complex structure of cellulose during coagulation process must be considered to discuss the morphological formation of the membrane besides simple phase equilibrium study. In addition, the transportation of substances during coagulation is also an important feature to clarify the morphological distribution in cross sectional (transverse) direction.

In this paper, we attempt to differentiate the morphologies of the regenerated cellulose membranes prepared from its cuprammonium hydroxide solution using various aq coagulants from the above mentioned view points.

\section{EXPERIMENTAL}

\section{Cellulose Solution}

Cotton linter supplied by Peterdemings Co., Ltd., was dissolved in aq cuprammonium hydroxide solution 
according to the known procedure ${ }^{9}$ at cellulose concentration of $8 \mathrm{wt} \%$. The molar composition of the solution (cellulose $/ \mathrm{Cu} / \mathrm{NH}_{3}$ ) was adjusted constant as $0.05 / 0.046 / 0.36$. The viscosity-average molecular weight of the cellulose recovered from the above solution by aq sulfuric acid was $1.7 \times 10^{5}$, as estimated by using the equation $[\eta]=3.85 \times 10^{-2} M_{w}{ }^{0.76}$ established for cellulose/cadoxen system. ${ }^{10}$

\section{Chemicals}

All chemicals employed were guaranteed grade and supplied from Wako Pure Chemicals Co., Ltd., Japan. They were diluted to the concentration of $10 \mathrm{wt} \%$ with deionized water and used as coagulants for membrane preparation and transportation test of components composing the original cellulose solution. Acids, alkalines and salts composing of cations $\left(\mathrm{H}^{+}, \mathrm{K}^{+}, \mathrm{Na}^{+}, \mathrm{NH}_{4}{ }^{+}\right.$, $\mathrm{Ca}^{2+}$, and $\mathrm{Mg}^{2+}$ ) and anions $\left(\mathrm{OH}^{-}, \mathrm{F}^{-}, \mathrm{Cl}^{-}, \mathrm{Br}^{-}\right.$, $\mathrm{CO}_{3}{ }^{2-}, \mathrm{SO}_{4}{ }^{2-}, \mathrm{CH}_{3} \mathrm{COO}^{-}$, and $\mathrm{C}_{2} \mathrm{O}_{4}{ }^{2-}$ ) were examined.

\section{Preparation of the Wet Regenerated Cellulose Membranes}

Cellulose solution was cast on a glass plate $(20 \times$ $19.4 \mathrm{~cm}$ ) to give thickness of $250 \mu \mathrm{m}$, immersing gently into coagulants $(500 \mathrm{ml})$ for $1 \mathrm{~min}$, washed by water at $40^{\circ} \mathrm{C}$ for $1 \mathrm{~min}$, and regenerated by $2 \mathrm{wt} \%$ aq sulfuric acid for $5 \mathrm{~min}$, followed by washing with water.

\section{Water Permeability of the Wet Membranes}

Water permeability UFR of the wet membranes with area of $2.4 \mathrm{~cm}^{2}$ was estimated from water flux under the pressure difference of $400 \mathrm{mmHg}$ at $25^{\circ} \mathrm{C}$, and expressed as $\mathrm{ml}\left(\mathrm{h} \cdot \mathrm{m}^{2} \cdot \mathrm{mmHg}\right)^{-1}$.

\section{Cross Sectional Morphological Distribution}

The wet membranes were frozen in liquid nitrogen and their cracked cross section sputtered with gold was subject to scanning electron microscopic observation at the accelerating voltage of $5 \mathrm{kV}$ (FE-SEM model S800 , Hitachi Co., Ltd., Japan). The five equally divided parts in membrane thickness direction for the electron micrographs obtained above were analyzed by high resolution imaging treatment system (IP-1000, Asahi Chemical Industry Co., Ltd., Japan) to evaluate the average pore size approximated as circular pore from the area $S$ of the pore part, by extracting pore parts with monitoring the difference in brightness. ${ }^{4}$ The average pore size of five parts are defined as $r_{1}, r_{2} \cdots, r_{5}$ from the front surface.

\section{Measurement of the Coagulated Gels}

$\mathrm{CD}$ spectra of the coagulated gels obtained during the coagulation procedure described in chemicals section in EXPERIMENTAL were recorded as a function of coagulation time on a spectrophotometer (Model J-720, JASCO, Japan) at $25^{\circ} \mathrm{C}$ in a quart cell with light pass length $=1 \mathrm{~mm}$, which was immersed in an excess amount of given coagulants for 1 to $30 \mathrm{~min}$, under the following conditions: Band width, $1.0 \mathrm{~nm}$; sensitivity, $1000 \mathrm{mdeg}$; response, $0.5 \mathrm{~s}$; scan speed, $500 \mathrm{~nm} \mathrm{~min}^{-1}$; wave length range, $800-200 \mathrm{~nm}$.

\section{Transportation of Substances from the Original Cellulose} Solution into Coagulants

In order to estimate the initial transportation rate of substances, $1 \mathrm{ml}$ of each coagulant was gently poured over $3 \mathrm{~g}\left(=W_{(0)}\right)$ of the cellulose solution (cellulose concentration, $\left.C_{\text {cell(0) }}\right)$ placed in a laboratory dish with area of $4.5 \mathrm{~cm}^{2}$ and stood for given contacting time $(5 \mathrm{~s}-$ $1 \mathrm{~min}$ ) at $26^{\circ} \mathrm{C}$. After each run (at a given contacting time), the resultant coagulant was removed and subject to analysis on cupric ion and ammonia transported into coagulant ( $W_{\mathrm{Cu}(\mathrm{c})}$ and $W_{\mathrm{NH}_{3}(\mathrm{c})}$, respectively) as described later. At the same time the weight of the resultant cellulose solution $\left(W_{(\mathrm{c})}\right)$ was measured. Using the initial amounts of substances $\left(\mathrm{Cu}, W_{\mathrm{Cu}(0)} ; \mathrm{NH}_{3}, W_{\mathrm{NH}_{3}(0)} ; \mathrm{H}_{2} \mathrm{O}\right.$, $\left.W_{\mathrm{H}_{2} \mathrm{O}(0)}\right)$ in the original cellulose solution, their transportation ratio are defined as follows:

$$
\begin{gathered}
\Delta W(\%)=100 W_{(\mathrm{c})} / W_{(0)} \\
\Delta \mathrm{Cu}(\%)=100 W_{\mathrm{Cu}(\mathrm{c})} / W_{\mathrm{Cu}(0)} \\
\Delta \mathrm{NH}_{3}(\%)=100 W_{\mathrm{NH}_{3}(\mathrm{c})} / W_{\mathrm{NH}_{3}(0)} \\
\Delta \mathrm{H}_{2} \mathrm{O}(\%)=100\left(W_{(\mathrm{c})}-W_{(0)}-W_{\mathrm{Cu}(\mathrm{c})}-W_{\mathrm{NH}_{3}(\mathrm{c})}\right) \\
/ W_{\mathrm{H}_{2} \mathrm{O}(0)}
\end{gathered}
$$

Cellulose concentration $\left(W_{\mathrm{Cel1}(\mathrm{c})}\right)$ after coagulation in the original solution is defined as

$$
W_{\mathrm{Cell}(\mathrm{c})}(\%)=C_{\mathrm{cell}(0)} /(100-\Delta W)
$$

Here, the transportation of substances composing coagulant into the cellulose solution was not considered. Therefore, $W_{\text {Cell(c) }}$ is liable to some error. In this paper, $\Delta \mathrm{NH}_{3}$ and $\Delta \mathrm{Cu}$ were mainly discussed.

Estimation of Copper Transported: Into the given volume of resultant coagulant $10 \mathrm{vol} \%$ of aq $15 \mathrm{wt} \%$ sulfuric acid solution was added to keep the $\mathrm{pH}$ of the sample solution below 2.0 and the absorbance of the solution at $810 \mathrm{~nm}$ was measured by a spectrophotometer (U-3400, Hitachi, Japan) and the copper concentration was determined from the calibration curve obtained for aq cupric sulfate.

Estimation of $\mathrm{NH}_{3}$ Transported: The given amount of resultant coagulant was colored by adding $o$-phthalaldehyde, excited by light with wave number of $390 \mathrm{~nm}$ and the intensity of fluorescence at $450 \mathrm{~nm}$ was measured by fluorescence photometer (F-4500, Hitachi, Japan). The intensity was transformed to amount using the calibration curve obtained for aq ammonium chloride in advance.

\section{RESULTS AND DISCUSSION}

Figure 1 shows electron micrographs of wet membranes with typical morphological distributions. Here, the front and back surfaces, the upper and the bottom sides in the photographs, respectively, mean the surfaces contacting coagulant and glass plate, respectively. It was demonstrated for the first time that the morphology in thickness direction can be categorized into four types depending on the coagulants. A is a gradient morphology where front surface is porous $\left(r_{1}=c a .350 \mathrm{~nm}\right)$ and the pore size gradually becomes small towards the back surface $\left(r_{5}=c a .120 \mathrm{~nm}\right)$ (Gradient I), B, a just reversed gradient morphology of $\mathrm{A}\left(r_{1}=c a .160 \mathrm{~nm}, r_{5}=c a .350\right.$ 


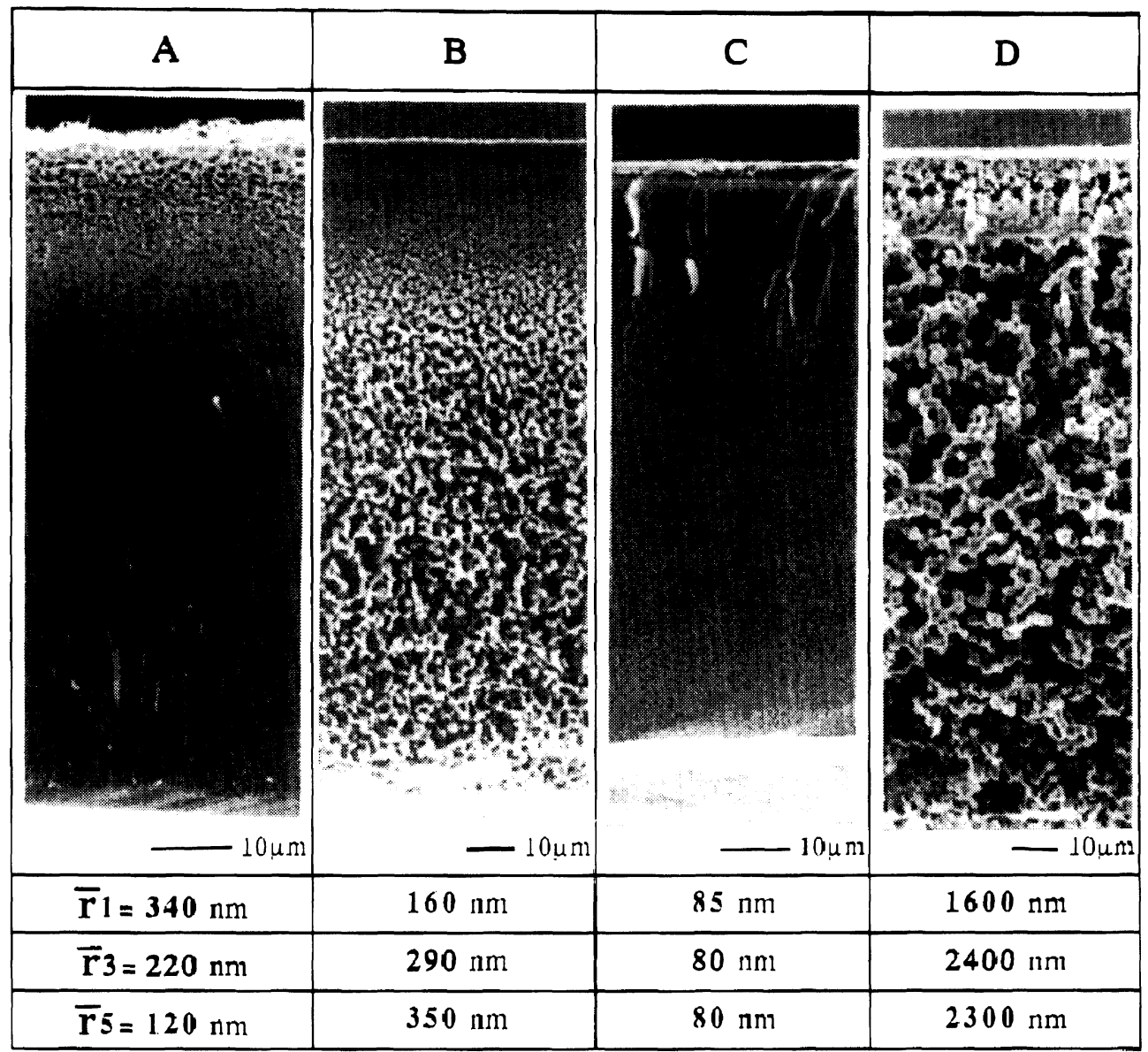

Figure 1. Typical cross sectional (thickness direction) views of the regenerated cellulose membranes recovered from its cuprammonium solution: A, Gradient I morphology (porous in front surface to which coagulant directly contacts); B, Gradient II morphology (porous in back surface which contacts with glass plate; C, homogeneous and dense (HD) morphology; D, skin-void (SV) morphology.

Table I. Morphology, membrane thickness, and water permeability of the regenerated cellulose membranes coagulated by various coagulants

\begin{tabular}{lcccccc}
\hline & $\mathrm{H}^{+}$ & $\mathrm{Na}^{+}$ & $\mathrm{K}^{+}$ & $\mathrm{NH}_{4}{ }^{+}$ & $\mathrm{Ca}^{2+}$ & $\mathrm{Mg}^{2+}$ \\
\hline $\mathrm{OH}^{-}$ & $\mathrm{A} / 199 / 110$ & $\mathrm{C} / 163 / 6$ & $\mathrm{C} / 115 / 6$ & - & - & - \\
$\mathrm{F}^{-}$ & - & $\mathrm{A} / 94 / 36$ & $\mathrm{~A} / 191 / 19$ & $\mathrm{~B} / 145 / 89$ & - \\
$\mathrm{Cl}^{-}$ & $\mathrm{B} / 157 / 90$ & $\mathrm{~A} / 93 / 28$ & $\mathrm{~A} / 98 / 29$ & $\mathrm{~B} / 144 / 134$ & $\mathrm{C} / 118 / 10$ & $\mathrm{D} / 168 / 124$ \\
$\mathrm{Br}^{-}$ & - & $\mathrm{A} / 91 / 11$ & $\mathrm{~A} / 189 / 15$ & - & $\mathrm{C} / 116 / 10$ & - \\
$\mathrm{SO}_{4}{ }^{2-}$ & $\mathrm{B} / 97 / 27$ & $\mathrm{~A} / 91 / 26$ & $\mathrm{~A} / 72 / 29$ & $\mathrm{~B} / 190 / 106$ & - & - \\
$\mathrm{CO}_{3}{ }^{2-}$ & - & $\mathrm{A} / 91 / 31$ & $\mathrm{~A} / 96 / 39$ & - & - \\
$\mathrm{CH}_{3} \mathrm{COO}^{-}$ & $\mathrm{B} / 153 / 101$ & $\mathrm{~A} / 88 / 28$ & $\mathrm{~A} / 95 / 28$ & $\mathrm{~B} / 215 / 101$ & $\mathrm{C} / 140 / 10$ & $\mathrm{D} / 240 / 302$ \\
$\mathrm{C}_{2} \mathrm{O}_{4}{ }^{2-}$ & $\mathrm{B} / 155 / 107$ & $\mathrm{~A} / 116 / 37$ & $\mathrm{~A} / 95 / 29$ & $\mathrm{~B} / 143 / 128$ & - & - \\
\hline
\end{tabular}

${ }^{a}$ A, Gradient I morphology (porous in front surface); B, Gradient II morphology (porous in reverse surface); C, homogeneously dense morphology; D, skin/void morphology. Numbers on second and third slashes mean the membrane thickness in wet ( $\mu \mathrm{m})$ state and water permeability $\mathrm{ml}\left(\mathrm{h} \cdot \mathrm{m}^{2} \cdot \mathrm{mmHg}\right)^{-1}$, respectively.

nm) (Gradient II); C, a homogeneously and densely coagulated morphology $\left(r_{1}=r_{5}=c a\right.$. $\left.80 \mathrm{~nm}\right)$ (HD); D, an exceptional skin/void morphology $\left(r_{1}=1600 \mathrm{~nm}, r_{5}=\right.$ ca. $2300 \mathrm{~nm})(\mathrm{SV})$.

The morphologies of the wet membranes obtained by using various coagulants are shown in Table I according to the classification of morphology described above. The table also lists the thickness and water permeability after first and second slashes, respectively. Morphology seems to be largely classified by $\mathrm{pH}$ of coagulants in general (neutral, A; acid, B; alkaline, C).

For salt coagulants, morphology of the wet mem- branes obtained is clearly dependent on cation not on anion. Salts of $\mathrm{Na}^{+}$and $\mathrm{K}^{+}$give $\mathrm{A}$ morphology, salts of $\mathrm{NH}_{4}{ }^{+}$give $\mathrm{B}$ and salts of $\mathrm{Ca}^{2+}$ give $\mathrm{C}$ morphologies. Magnesium salts giving $\mathrm{D}$ morphology is exceptional and the reason will be discussed later. Membranes with $\mathrm{C}$ morphology are resistant to water permeability and those with B morphology shows highest water permeability. The wet membranes with larger thickness tend to exhibit higher water permeability with a very few exceptions. Note that anion species give almost no influence also on the water permeability.

Figure 2 shows CD spectra of the coagulated gels as 


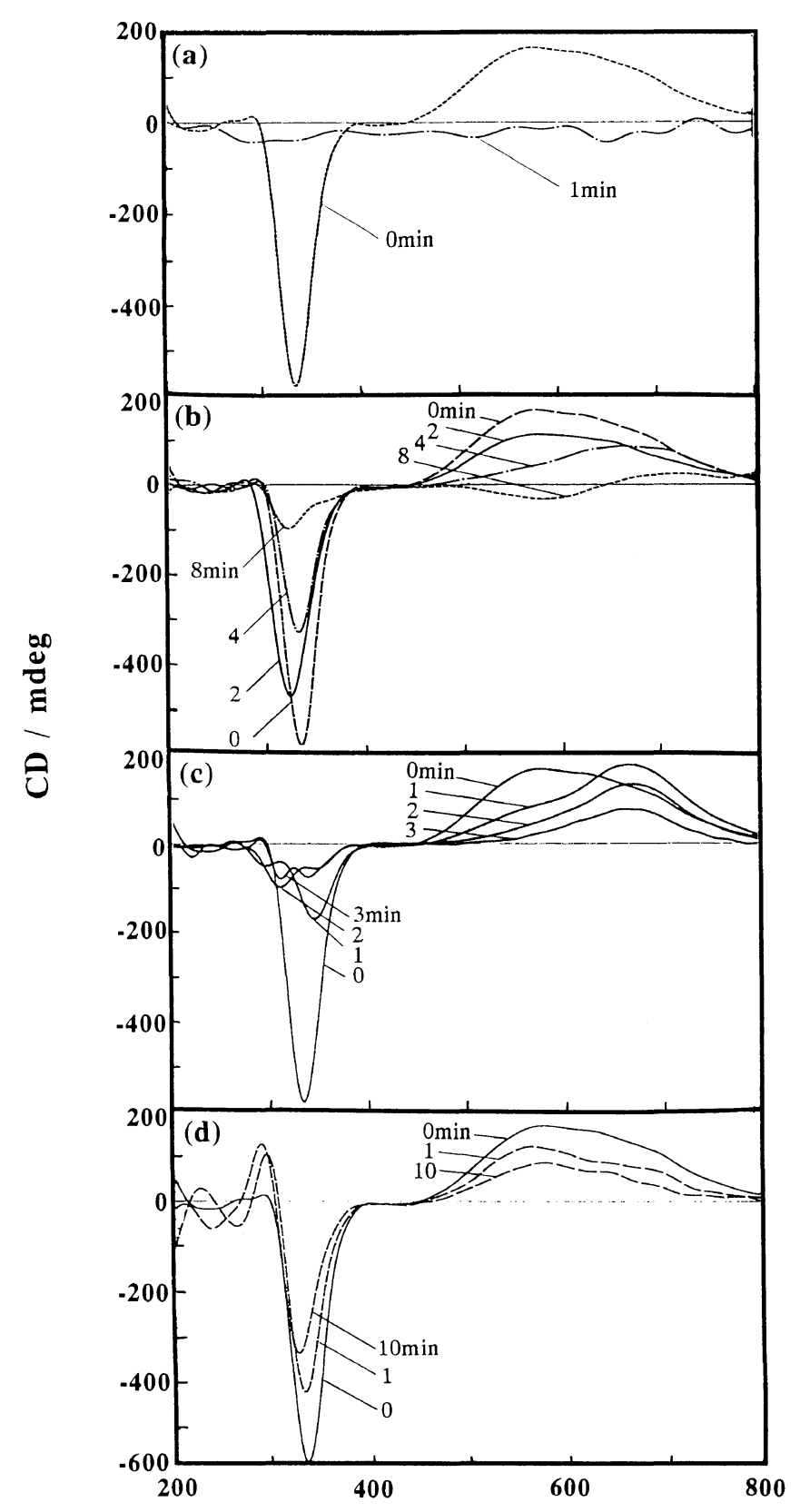

Wave length / nm

Figure 2. $\mathrm{CD}$ spectra of the coagulated gels as a function of coagulation time: $\mathrm{a}, \mathrm{H}_{2} \mathrm{SO}_{4}$ or $\mathrm{NH}_{4} \mathrm{Cl}$; b, water or $\mathrm{NaCl} ; \mathrm{c}, \mathrm{CaCl}_{2} ; \mathrm{d}, \mathrm{MgCl}_{2}$. Numbers on the figure mean coagulation time expressed in min and 0 means the original cellulose solution.

a function of contact time $\left(\mathrm{a}, \mathrm{H}_{2} \mathrm{SO}_{4}, \mathrm{NH}_{4} \mathrm{Cl}\right.$; b, water, $\mathrm{NaCl} ; \mathrm{c}, \mathrm{CaCl}_{2} ; \mathrm{d}, \mathrm{MgCl}_{2}$ ). Numbers on the figure denote the coagulation time expressed in min $(0$ means the original cellulose solution). The original solution exhibits a negative CD peak at $c a .330 \mathrm{~nm}$ responsible for the complex of cellulose with cuprammonium hydroxide (hereafter referred to as Peak I) and at least three d-d positive excitations for cupric ion around 560 , 620 , and $690 \mathrm{~nm}$ (hereafter referred to as peak $\mathrm{II}_{1}, \mathrm{II}_{2}$, $\mathrm{II}_{3}$, respectively). For the original solution the $\mathrm{II}_{1}$ peak shows maximum intensity. In the case of aq $\mathrm{H}_{2} \mathrm{SO}_{4}$ and aq $\mathrm{NH}_{4} \mathrm{Cl}$ coagulants, both the original peaks I and II disappeared at coagulation time $=1 \mathrm{~min}$ due to complete regeneration (decomposition of the complex) of cellulose.
When water and aq $\mathrm{NaCl}$ are used as coagulants, the intensity of peak I gradually decreases with an increase in coagulation time with some shorter wave number shift and peak II also decreases accompanying the shift of maximum peak position to longer wave number, followed by the change of CD appearance from positive to negative. The reason is not clear at present, but it can be said that some form of chirality between cellulose with cupric ion remains. Aq $\mathrm{CaCl}_{2}$ revealed that peak I abruptly decreases in its intensity, followed by splitting of the peak into two peaks, and peak II clearly changes its maximum peak position to $c a$. $690 \mathrm{~nm}\left(\mathrm{II}_{3}\right)$ and decreases with an increase in coagulation time but with keeping its symbol (positive). This might mean that a new type of complex between cellulose and cuprammonium hydroxide is formed. In the initial stage of coagulation (up to coagulation time of $10 \mathrm{~min}$ ) $\mathrm{MgCl}_{2}$ showed similar tendency to that seen for water coagulation but the prolonged coagulation time never causes the change in the shape of CD spectra any more. This means that coagulation did not proceed after $10 \mathrm{~min}$. In fact we observed a white solid formed in the boundary of the cast solution and the coagulant and we measured CD spectrum again for the resultant solution after the removal of the white solid and confirmed that it was exactly the same as the original cellulose solution. The white solid, which works as a barrier against the penetration of coagulant, might be the product (magnesium hydroxide) according to the following chemical reaction.

$$
\mathrm{MgCl}_{2}+2 \mathrm{NH}_{3}+\mathrm{H}_{2} \mathrm{O} \rightarrow \mathrm{Mg}(\mathrm{OH})_{2}+2 \mathrm{NH}_{4} \mathrm{Cl}
$$

This was also affirmed by ESCA analysis on the white solid, which revealed the molar composition of $\mathrm{Mg}: \mathrm{Cu}: \mathrm{O}: \mathrm{C}: \mathrm{Cl}=1.0: 0.1: 2.6: 0.5: 0.1$.

All the above results are summarized as follows: 1) The original cellulose solution becomes gelatinous by accompanying the change in complex form in two ways; 2) The original cellulose solution is easily regenerated with a sudden removal of copper, hence accompanying the complete decomposition of the complex; 3) foreign substance is formed at boundary of the cellulose solution and coagulant.

The above observations well coincide with the results for morphological observation as discussed before. Further, the change in CD spectra as a function of coagulation time should correspond with the material transportation in part.

Transportation of copper and ammonia from the original solution $\left(\Delta \mathrm{Cu}, \Delta \mathrm{NH}_{3}\right)$ for typical coagulants are shown in Figure 3 . The orders of $\Delta \mathrm{Cu}$ and $\Delta \mathrm{NH}_{3}$ are as follows from higher: $\mathrm{H}_{2} \mathrm{SO}_{4}>\mathrm{NH}_{4} \mathrm{Cl}>\mathrm{CaCl}_{2}>$ $\mathrm{NaCl} \gg \mathrm{MgCl}_{2}=c a$. 0 and $\mathrm{H}_{2} \mathrm{SO}_{4}>\mathrm{CaCl}_{2}>\mathrm{NaCl}>$ $\mathrm{NH}_{4} \mathrm{Cl} \gg \mathrm{MgCl}_{2}$, respectively. Higher removability of copper for $\mathrm{H}_{2} \mathrm{SO}_{4}$ and $\mathrm{NH}_{4} \mathrm{Cl}$ corresponds to the decomposition of complex, as proved by $\mathrm{CD}$ analysis. $\mathrm{NaCl}$ and $\mathrm{CaCl}_{2}$ revealed the relatively higher removable of ammonia than copper and this tendency is more favorable of $\mathrm{CaCl}_{2}$. This is also comparable to the result of $\mathrm{CD}$ analysis, where $\mathrm{NaCl}$ coagulation is much slower than that of $\mathrm{CaCl}_{2}$. The lowest removability of copper and ammonia for $\mathrm{MgCl}_{2}$ is attributable to the formation of magnesium hydroxide, which acts as a barrier for copper and ammonia transportation, as described before. 

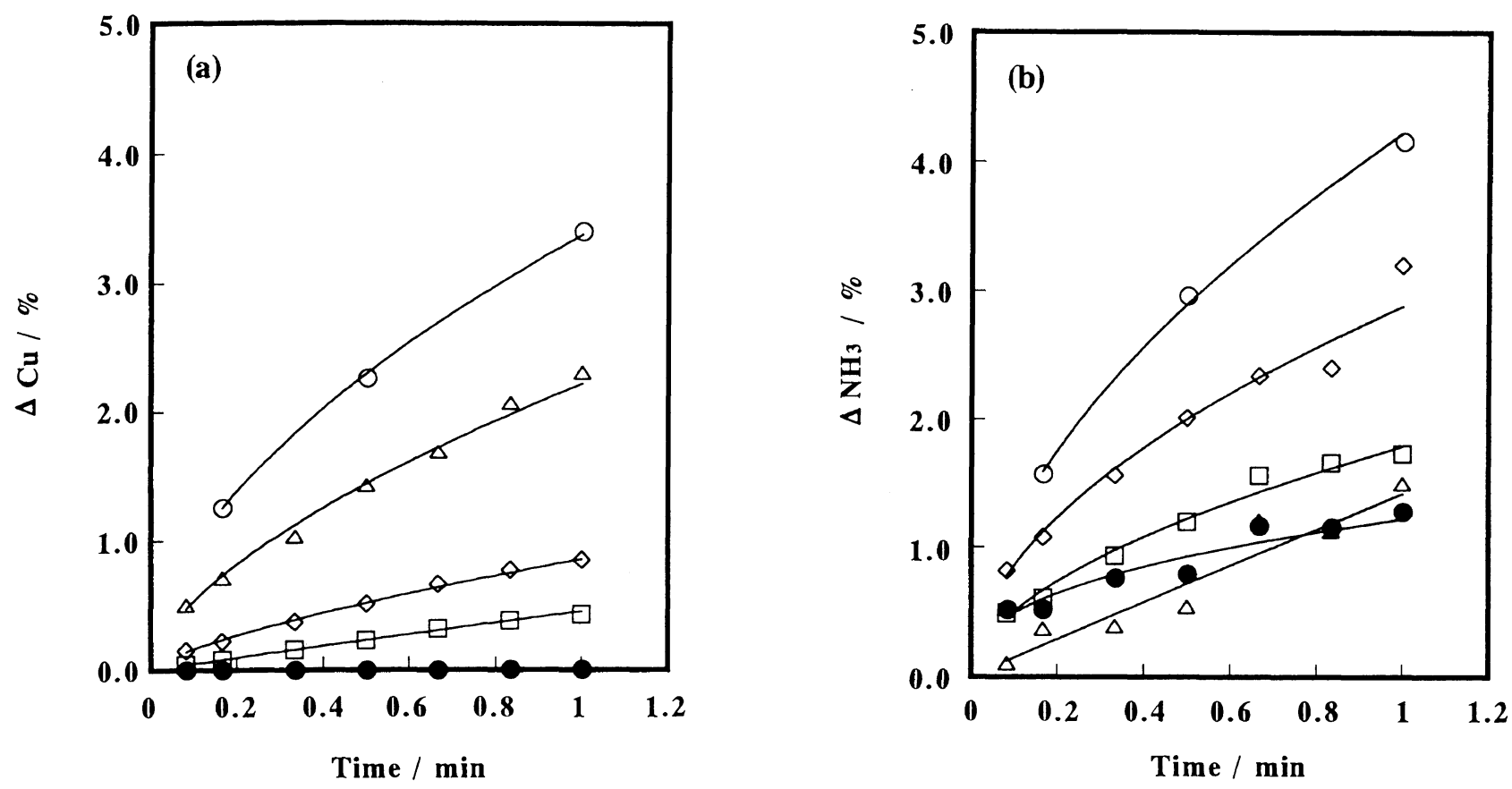

Figure 3. Transportation of copper $(\Delta \mathrm{Cu})$ and ammonia $\left(\Delta \mathrm{NH}_{3}\right): \bigcirc, \mathrm{H}_{2} \mathrm{SO}_{4} ; \Delta, \mathrm{NH}_{4} \mathrm{Cl} ; \square, \mathrm{NaCl} ; \diamond, \mathrm{CaCl} ; \mathrm{O}, \mathrm{MgCl}$.

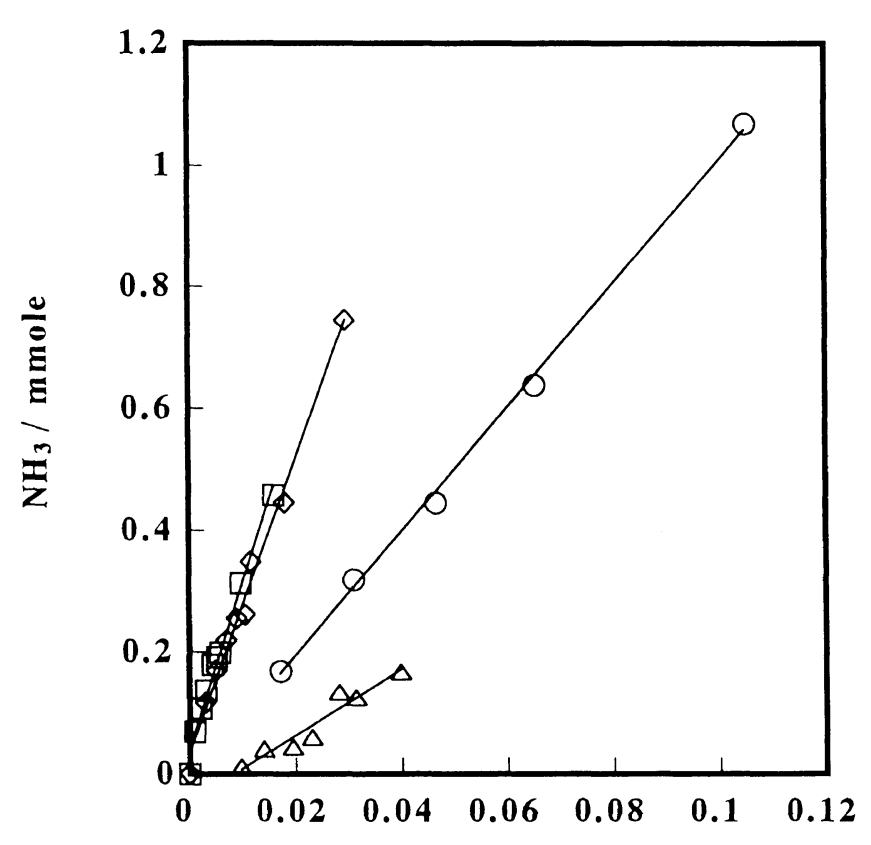

$\mathrm{Cu} /$ mmole

Figure 4. Relation between the molar number of $\mathrm{NH}_{3}$ and that of copper, transported into various coagulants: $\mathrm{O}, \mathrm{H}_{2} \mathrm{SO}_{4} ; \triangle, \mathrm{NH}_{4} \mathrm{Cl}$; $\square, \mathrm{NaCl} ; \diamond, \mathrm{CaCl}_{2}$.

Thus, for magnesium cation coagulation, the morphology of the membrane is mainly determined by the subsequent washing and regeneration processes.

On the basis of data points in Figure 3, absolute mole numbers of $\mathrm{NH}_{3}$ and $\mathrm{Cu}$ transported at given coagulation times, which are reduced from $\Delta \mathrm{NH}_{3} v s . \Delta \mathrm{Cu}$ (both $\mathrm{wt} \%$ basis), are plotted each other to seek for some linearity due to certain a definite forms of cuprammonium complex when transported to coagulant. This is shown in Figure 4. Obviously the straight lines are resulted for each coagulant, indicating that the trans- ported molar ratio of $\mathrm{NH}_{3} / \mathrm{Cu}$, as estimated from the slope, is constant for a given coagulant. The order of the transported molar ratio is followings: $\mathrm{NH}_{4} \mathrm{Cl}(5.24$ mol mol $\left.{ }^{-1}\right)>\mathrm{H}_{2} \mathrm{SO}_{4}(10)>\mathrm{NaCl}=\mathrm{CaCl}_{2}$ (26). $\mathrm{H}_{2} \mathrm{SO}_{4}$ coagulation might take place drastically by decomposition of complex (regeneration).

In the case of $\mathrm{NH}_{4} \mathrm{Cl}$, the less transportation of $\mathrm{NH}_{3}$ compared with that $\mathrm{H}_{2} \mathrm{SO}_{4}$ might be explained by the following formula:

$$
\begin{aligned}
& {\left[\mathrm{Cu}\left(\mathrm{NH}_{3}\right)_{4}(\mathrm{OH})_{2}\right]+2 \mathrm{NH}_{4} \mathrm{Cl} \rightarrow} \\
& {\left[\mathrm{Cu}\left(\mathrm{NH}_{3}\right)_{4}\right] \mathrm{Cl}_{2}+2 \mathrm{NH}_{4} \mathrm{OH}}
\end{aligned}
$$

The above formulae is comparative to that for the obtained transported molar ratio.

The coagulation systems which accompany the change in complex gave far larger molar ratio, indicating that cupric ion tends to cling to the resulting new complex/ compared with ammonia, resulted in very slow transportation of copper.

\section{CONCLUSION}

The morphology in thickness direction of the regenerated cellulose membranes recovered from cellulose/ cuprammonium hydroxide solution using various aqueous coagulants was proved to be mainly categorized into four types depending on $\mathrm{pH}$ and cation species of coagulant and be controlled by the complex forms of the coagulated gel, of which changes as a function of coagulation time influenced the transportation of components in original cellulose solution into coagulation bath. The membranes with gradient pore distribution having relatively larger water permeability was proved to be obtainable by using acids or ammonium salts coagulants. The results also suggests that phase separation phenomena observed for the cellulose/cuprammonium hydroxide solution and non-solvent system should be analyzed by considering the change in complex form. 


\section{REFERENCES}

1. F. Gejyo, T. Yamada, and S. Odani, Biochem. Biophys. Res. Commun., 129, 701 (1985).

2. C. Yamane, M. Mori, M. Saito, and K. Okajima, submitted to Polym. J.

3. M. Tsuge, S. Uematsu, Y. Ono, S. Eiga, and M. Makita, Japan Open Patent, 49-31912 (1974).

4. S. Manabe, Y. Shigemoto, H. Iijima, and K. Kamide, Polym. J., 19, 4, 391 (1987).

5. Y. Hamamoto, S. Harada, S. Kobayashi, K. Yamaguchi, H.
Iijima, S. Manabe, H. Aizawa, and N. Yamamoto, Vox Sang, 56, 230 (1989).

6. S. Manabe, H. Iijima, and K. Kamide, Polym. J., 20, 4, 307 (1988).

7. I. Miyamoto, M. Inamoto, T. Matsui, M. Saito, and K. Okajima, Polym. J., 27, 1113 (1995).

8. I. Miyamoto, Y. Matsuoka, T. Matsui, M. Saito, and K. Okajima, Polym. J., 27, 1123 (1995).

9. W. Gibson, L. Spencer, and R. McCall, J. Chem. Soc., 117, 479 (1920).

10. W. Brown and R. Wikström, Eur. Polym. J., 1, 1 (1965). 